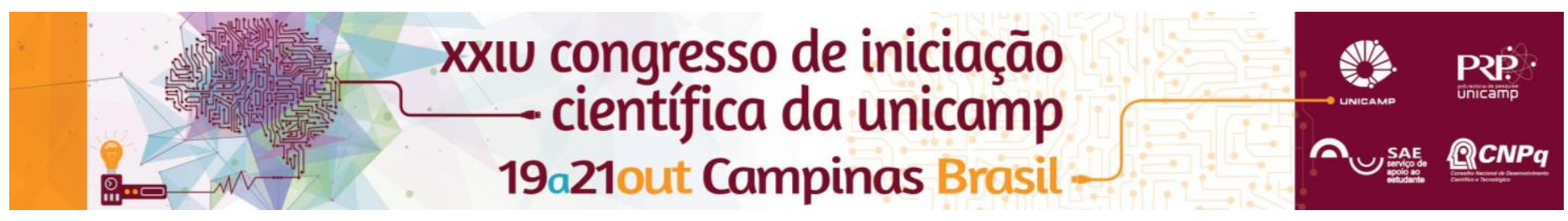

\title{
O BRINCAR NO COTIDIANO DE UMA ESCOLA DE TEMPO INTEGRAL
}

\author{
Gabriel da C. Spolaor*, Elaine Prodócimo.
}

\begin{abstract}
Resumo
Considerando o brincar como manifestação presente nas Escolas de Tempo Intergral (ETIs), tivemos como objetivo neste trabalho, analisar o brincar das crianças de $1^{\circ}$ ano durante o cotidiano de uma escola de ciclo I do ensino fundamental da Prefeitura de Campinas, assim como investigar os seus sentido/significados na perspectiva dos docentes da turma. Como procedimentos metodológicos, realizamos uma pesquisa de cunho qualitativo, utilizando observações e entrevistas semi-estruturadas. Sobre os sentidos/significados dados para o brincar percebemos que existe uma grande pluralidade. Foi possível dividí-los em 2 grupos: institucionalizado e não-institucionalizado.
\end{abstract}

\section{Palavras-chave: Escola de Tempo Integral, Brincar, Cotidiano escolar.}

\section{Introdução}

Nos últimos anos foi possível observar um aumento das (ETI's) em diversos níveis, de todas as redes públicas de ensino do Brasil. O brincar entendido aqui como um direito social, como manifestação construída culturalmente (BOUGÈRE, 1998), importante para o desenvolvimento e aprendizagem cultural da criança (VIGOTSKI, 2007) se faz presente dentro do cotidiano (entrada, aulas, oficinas, recreios, refeições, saída) das ETI's e assume diferentes sentidos/significados. Nessa pesquisa tivemos 0 objetivo de analisar os sentidos/significados referentes ao brincar dentro desse modelo de escola, na perspectiva dos professores que atuam com uma turma de $1^{\underline{0}}$ ano do Ensino Fundamental. Buscamos analisar também a existência, quantidade e qualidade de tempos e espaços específicos para que o brincar aconteça, as brincadeiras presentes no cotidiano, o papel assumido pelos profissionais durante esse brincar, assim como, compreender a relação desta manifestação com a prática pedagógica.

\section{Método}

Como procedimentos metodológicos, realizamos uma pesquisa de cunho qualitativo utilizando observações e entrevistas semiestruturadas como técnicas de coletas de dados. Foram realizados 13 dias de observações do cotidiano de uma turma de $1^{\circ}$ ano. Observamos 13 entradas, 5 saídas, 33 aulas, 31 refeições e 13 recreios. Como critério para as entrevistas, escolhemos os professores que haviam sido observados durante a pesquisa, totalizando 4 entrevistas semiestruturadas com professores das disciplinas de Educação Física, Português/Matemática, Artes e Projetos.

\section{Resultados e Discussão}

Sobre os sentidos/significados dados para o brincar percebemos que existe uma grande pluralidade. Nas entrevistas destacamos alguns destes discursos que explicitam os significados: "Brincar é tudo de bom"; "capacidade de estar inteiro no que está fazendo"; "forma de diálogo da criança com o mundo"; "tempo de lazer, entrega, prazer, divertimento"; "espaço de relação com o mundo de maneira espontânea"; "momento de descontração, de extravasar, de relaxar; espaço de aprendizado". Por outro lado, ao longo das observações foi possível reconhecer outros significados que ora se aproximam e ora se distanciam dos discursos mostrados. Eles se materializam nos usos que o brincar assume, assim como, em meio as práticas pedagógicas dos docentes. As crianças brincam ao longo de todo cotidiano escolar, desde a entrada até a saída. De acordo com os momentos desse cotidiano o brincar recebe diferentes significados. Dividimos estes significados em 2 grupos: institucionalizado e nãoinstitucionalizado. No primeiro identificamos o brincar chamado de livre no recreio e no dia do brinquedo; as brincadeiras pedagógicas que tentam criar situações lúdicas de aprendizado dentro da sala de aula; o brincar como conteúdo da própria disciplina; o brincar como relaxamento para que as crianças "aguentem" os conteúdos; brincar como forma de controle do comportamento (na maioria das vezes para silenciar a turma e para se movimentar de um determinado modo nos espaços da escola). No segundo grupo identificamos o brincar que mais se afasta dos discursos e que não é proposto pelos docentes, mas que é criado pelas próprias crianças permeando todo o cotidiano da escola: brincadeiras de empurrar e de corrida nas filas, cambalhotas e estrelas no meio da sala de aula, guerras de água e papel no banheiro, conversas e criação de brinquedos durante as explicações, gritos e palmas nas refeições etc. Todo esse conjunto de brincadeiras tem um caráter de resistência/subversão às regras da escola, e por várias vezes é significado como bagunça, loucura, desordem. Muitas vezes as crianças são repreendidas por brincar, recebendo chamadas de atenção, castigos (perdendo tempo de recreio) ou tendo que brincar de algo proposto pelo professor como forma de controle.

\section{Conclusões}

Entendemos que este trabalho contribui para a reflexão sobre a importância do espaço do brincar e de como é significado, utilizado e compreendido dentro de uma ETI, mostrando que na atuação dos professores ainda é possível identificar descontinuidades entre os discursos e as suas práticas pedagógicas.

\section{Agradecimentos}

Agradecemos ao CNPQ e a Pró-reitoria de pesquisa (PRP) da UNICAMP que concedendo financiamento via bolsa PIBIC, tornou possível a realização desta pesquisa.

\footnotetext{
${ }^{1}$ BROUGÈRE, G. A criança e a cultura lúdica. Rev. Fac. Educ., São Paulo, v. 24, n. 2, Julho, 1998.

${ }^{2}$ VIGOTSKI, L.S. A formação social da mente: o desenvolvimento dos processos psicológicos superiores. Michael Cole et. al $7^{\mathrm{a}}$. Edição. São Paulo. Martins Fontes. 2007.
} 